\title{
PROPHETIC PARENTING SEBAGAI MODEL PENGASUHAN DALAM PEMBENTUKAN KARAKTER (AKHLAK) ANAK
}

\author{
Yulia Hairina
}

\author{
Fakultas Ushuluddin dan Humaniora \\ IAIN Antasari Banjarmasin
}

Diterima tanggal 10 Januari 2016 / Disetujui tanggal 15 Maret 2016

\begin{abstract}
:
Children are an mandate from Allah to all parents. They must give them a good education in order to be good Muslims and they worship to Allah. Parents are the first teachers who have a responsibility in developing children's psychology both of spiritual and physical needs. In this case, parents have main position in forming the children's character. This era, there are children do many deviations more and more. It indicates that there is something lack in model of nurture by the parents. The model of nurture applied by parents to their children determines the children's character. The model of nurture in characters building had taught by prophets. Allah had delegated all prophets to the world by giving a main mission that is the character building. Islam is present as a movement to complete the human's character. Islam explains that a good education is the children's right to their parents. The good education means here is an education based on the Quran and the purposes to build the Muslim personality, who totally allows to the God, by guidance had tanght by Prophet Muhammad (pbuh). This writing is aimed at describing education method and concept in progressing character building for children, which had done Prophet Muhammad (pbub) and it will be related to Psychology.
\end{abstract}

Kata kunci: Prophetic Parenting, Amanah, Pengasuban, Karakter

\section{Pendahuluan}

Anak adalah anugerah Allah yang di amanahkan kepada orangtua dan wajib disyukuri. Seperti yang telah dikatakan oleh Imam al-Ghazali bahwasanya:

"Anak adalah amanat di tangan kedua orangtuanya. Hatinya yang suci adalah mutiara yang masih mentah, belum dipahat maupun dibentuk. Mutiara ini dapat dipahat dalam bentuk apapun, mudah condong kepada segala sesuatu. Apabila dibiasakan dan diajari dengan kebaikan, maka dia akan tumbuh dalam kebaikan itu“. 1

Pendidikan di dalam keluarga adalah pendidikan awal dan utama bagi seorang manusia, yang mana memberi pengaruh pertama pada anak. Pembentukan pribadi anak saat itu masih menerima segala sesuatu dan mudah terpengaruh oleh apapun dalam bentukan lingkungan pertama ini. Sehingga, kunci utama dalam pembentukan karakter anak terdapat dalam keluarga terutama orang tua.

Sarlito Wirawan Sarwono mengemukakan bahwa: Menurut aliran emprisme yang dipelopori oleh John Locke (1632-1704) mengatakan bahwa: "Manusia itu sewaktu labirnya adalah putih bersih, bagaikan tabularasa, menjadi apakah anak itu kelak sepenubnya tergantung pada pengalaman-pengalaman yang akan mengisi tabularasa tersebut"

Kemudian aliran ini juga diikuti oleh Watson sebagai pelopor aliran behavioris yang mengatakan jiwa manusia itu sewaktu lahirnya adalah bersih, maka yang akan memberikan pengaruh terhadap pendidikan anak 
adalah lingkungan dan pengalaman-pengalaman yang di laluinya. Oleh karena itu peran orang tua adalah menyesuaikan diri anak dengan lingkungan dan pengalaman yang dikehendakinya. ${ }^{3}$

Dalam hadits yang diriwayatkan oleh Bukhari dari Abu Hurairah r.a bahwa Rasulullah SAW bersabda: "Setiap bayi dilabirkan atas fitrah, maka orang tuanyalah yang menjadikannya Yabudi, Nasrani dan Majusi." 4

Dari pendapat tokoh psikologi dan hadits di atas maka penulis menyimpulkan bahwa sangatlah penting lingkungan dalam tulisan ini yaitu pendidikan dalam keluarga (orangtua) untuk membentuk karakter (akhlak) anak. Dengan pendidikan yang baik akan didapat karakter atau akhlak yang mulia sebagai fondasi yang kuat dalam mempersiapkan pribadi yang saleh dan bertanggung jawab atas segala persoalan dan tugas hidupnya. ${ }^{5}$

Salah satu tanggung jawab yang harus diberikan orangtua atas anak yang diamanahkan kepada mereka adalah dengan berusaha mendidik mereka sebaik-baiknya melalui pola asuh yang tepat, karena tanpa pendidikan dan pola asuh yang tepat, rasanya mustahil mereka akan menjadi generasi yang berkualitas yang shalih dan shalihah. ${ }^{6}$ yaitu sebuah generasi yang memiliki karakter dan memiliki nilai-nilai kepribadian Islami serta iman dan Islam yang kuat.

Peran, sikap dan perilaku orangtua dalam proses pengasuhan anak, sangat besar pengaruhnya dalam pembentukan dan perkembangan kepribadian anak. Pola asuh yang diterapkan oleh orang tua kepada anaknya akan menentukan baik atau tidaknya akhlak anak tersebut. Abu 'Ala berkata dalam syairnya Al-Bayan:

Akan tumbuh dan berkembang seorang anak sebagaimana perlakuan dan pembiasaan orang tuanya terhadapnya, anak tidak mungkin menjadi hina dan tercela.

Apabila kita memahami betapa besar pengaruh lingkungan rumah bagi kehidupan anak maka kedua orang tuanya memiliki kewajiban penuh dalam mempersiapkan anak dan melindunginya dari kehinaan serta mengarahkannya agar tumbuh di dalam jiwanya ruh agama dan kemuliaan.

Pola asuh sendiri merupakan bentuk perlakuan orang tua terhadap anak, sedangkan menurut Moh. Shochib dalam bukunya menyebutkan bahwa pola asuh yang dibutuhkan anak dari orang tuanya adalah kemampuan orang tua dalam menghayati kewajiban atau tugasnya sebagai pengasuh yang dapat membantu anak dalam memiliki dasar-dasar moral, kontrol diri, suasana psikologi serta bersosialisasi. ${ }^{7}$

Namun, proses pengasuhan orangtua tidak selalu sesuai dengan yang diharapkan dan tidaklah sesederhana yang kita bayangkan dan katakan. Pada kenyataannya pada kondisi sekarang ini masih banyak orang tua yang kurang menyadari apa penyebab dari tingkah laku anak mereka. Orang tua lebih melempar tanggungjawab pembinaan anak sepenuhnya kepada pihak sekolah. Padahal penanaman karakter pada diri anak bukan hanya tanggung jawab guru di sekolah, artinya tidak harus melalui jalur pendidikan formal. Namun orang tua sebagai pemilik anak yang sesungguhnya memiliki tanggung jawab yang sangat besar dan utama dalam hal ini. Banyak kasus kenakalan yang dilakukan oleh anak lebih banyak disebabkan karena 
kondisi orang tua sendiri, seperti kurangnya kasih sayang dan perhatian orang tua, kurangnya pendidikan yang diberikan kepada anak di rumah, kondisi keluarga yang tidak harmonis dan lain sebagainya.

Di era globalisasi saat ini merupakan tantangan besar bagi orang tua dalam upaya mendidik dan mengasuh anak. Teknologi yang semakin canggih dan akses informasi yang semakin mudah sedikit banyak mempengaruhi perkembangan jiwa anak. Akibatnya, fenomena di masyarakat kita saat ini terhiasi dengan kian maraknya tawuran antar pelajar, geng motor, perilaku remaja yang menyimpang, seks bebas, pornografi, bullying dan masih banyak kasus-kasus lainnya. Perilaku-perilaku anak seperti yang diuraikan di atas tidak serta merta terjadi begitu saja, melainkan melalui suatu proses pembelajaran dengan kondisi dan situasi yang terjadi di sekitar kehidupannya. Anak dengan segala perilakunya, membawa suatu model dan bentuk karakter dalam dirinya, yang diperoleh dari atau dibentuk oleh lingkup kehidupannya, terutama dari orangtua.

Para orang tua lebih tertarik mendidik anak dengan pola kebebasan dan memberi ruang cukup besar untuk anak melakukan hal yang disenanginya. Ruang demokrasi kebablasan dibangun atas nama pendidikan ala modern. Banyak kelonggaran diberikan pada anak asalkan anak merasa senang, bahkan tidak jarang orang tua memberikan fasilitas game online atau handphone atau i-pad pada anak dengan alasan agar anak tidak menangis, rewel, dan mengganggu orang tuanya.

Pada akhirnya orang tua juga yang banyak mengeluh atas kenakalan anak-anak mereka yang sukar dikendalikan, keras kepala, tidak mau menurut perintah orang tua, sering berkelahi, tidak mau belajar, merusak milik orang lain, merampok, menipu dan suka berbohong serta kerendahan moral lainnya. Kasuskasus itu antara lain disebabkan ketidaktahuan orang tua akan pentingnya mengasuh dan mendidik anak dengan baik, ini menjadikan anak sebagai korban, orang tua selalu menyalahkan anak, tanpa mereka sadari bahwa apa yang sekarang menjadi kepribadian anak adalah hasil dari pola asuh yang orang tua terapkan pada anak, orang tua mungkin cenderung bersikap kasar, otoriter, acuh tak acuh, atau terlalu memanjakan anak, sehingga anak tumbuh menjadi sosok yang egois, agresif, dan kesulitan dalam bersosialisasi, dan lain-lainnya. Jika kondisi ini dibiarkan, kasus-kasus seperti ini nampaknya akan terus meluas seiring perkembangan kemajuan zaman. Dan jika hal ini terus berlanjut maka anak sebagai generasi masa depan tidak mempunyai dasar karakter yang kuat dalam menghadapi tantangan zaman.

Melihat adanya kenyataan tersebut mengindikasikan perlunya pengembangan pendidikan karakter pada anak melalui pola asuh yang tepat oleh orangtua; tidak sekedar pengetahuan atau kecerdasan intelektual semata, tetapi juga menjangkau dalam wilayah moral atau kepribadian. Pendidikan karakter memiliki sifat bidireksional (dua arah) dimana arahannya adalah anak mampu memiliki ketajaman intelektual dan integritas diri sebagai pribadi yang memiliki karakter kuat. ${ }^{8}$ Hal ini senada seperti yang diungkapkan Thomas Lickona ada tiga komponen karakter yang baik (components of good character) yang harus terintegrasi dalam pembentukan karakter, yaitu: knowing the good (moral knowing), feelling the good (moral feeling), dan acting the good (moral action). ${ }^{9}$

Sebagai muslim dan muslimin kita tidak perlu menengok ke dunia pendidikan Barat dalam mengatasi problem yang kita hadapi. Agama yang kita peluk adalah agama sempurna yang memiliki metode dalam 
mengatasi segala kesulitan termasuk yang menyangkut masalah mengasuh anak. Selama ini kita mungkin lebih banyak mengadopsi ajaran-ajaran maupun pemikiran barat untuk kita gunakan sebagai pedoman hidup kita. Padahal kita mempunyai sosok manusia yang diciptakan Allah SWT. sebagai sosok teladan yang wajib kita ikuti. Rasulullah saw. Allah SWTT berfirman dalam surat al-Ahzab ayat 21:

Sesungguhnya telah ada pada (diri) Rasulullah itu suri teladan yang baik bagimu (yaitu) bagi orang yang mengharap (rahmat) Allah dan (kedatangan) hari kiamat dan dia banyak menyebut Allah.

Sebuah hadist menegaskan bahwa tugas utama kerasulan Muhammad SAW adalah untuk menyempurnakan akhlak (karakter). Ini berarti telah ada benih akhlak pada masing-masing manusia, tinggal bagaimana lingkungan pendidikan dapat mengoptimalkan benih-benih tersebut. Sebagaimana sabda Rasulullah SAW yang artinya, "Sesunggubnya aku diutus ke muka bumi ini adalah untuk menyempurnakan akblak manusia". (HR. Ahmad, Baihaqi, dan Malik). ${ }^{10}$

Pendidikan karakter merupakan misi utama para rasul diutus Allah di muka bumi. Dan Islam hadir sebagai gerakan untuk menyempurnakan karakter. Islam menegaskan bahwa pendidikan yang baik adalah hak anak atas orang tua dan pendidikan yang baik yang dimaksud Islam adalah pendidikan yang sesuai dengan tuntunan al-Qur'an dan tujuan-tujuannya dalam membentuk kepribadian muslim yang berserah diri secara total kepada Tuhannya dengan tuntunan yang telah diajarkan oleh Rasulullah saw.

Berdasarkan ayat dan hadist tersebut sangat jelas bahwa Rasulullah di utus sebagai suri teladan atau figur terbaik yang harus diikuti seluruh umat manusia termasuk cara mendidik anak. Metode pendidikan yang telah diajarkan oleh Rasulullah SAW empat belas abad yang lalu sudah seharusnya menjadi teladan dalam setiap langkah tidak terkecuali dalam pengasuhan anak, Rasulullah SAW menjadi contoh seorang pendidik yang sempurna. Maka dari itu, penulis perlu menggali lebih dalam bagaimana konsep dan metode Rasulullah dalam hal pembentukkan karakter pada anak khususnya akan diintegrasikan dari sisi psikologis .

\section{Pola Asuh Orangtua}

Secara umum pola asuh orang tua adalah perlakuan orang tua dalam rangka berinteraksi dengan anak untuk menanamkan pendidikan, memenuhi kebutuhan, melatih sosialisasi, serta memberikan perlindungan dalam kehidupan sehari-hari.

Parenting adalah pekerjaan dan keterampilan orang tua dalam mengasuh anak. Menurut Fauzil adhim, pola asuh adalah sikap orang tua terhadap anak mempengaruhi bagaimana orang tua memperlakukan anak, mendidik dan mengasuh anak, menghadapi perilaku-perilaku anak maupun kenakalan anak. ${ }^{11}$

Menurut Chabib Thoha, pola asuh merupakan suatu cara terbaik yang ditempuh oleh orang tua dalam mendidik anak sebagai perwujudan dari rasa tanggung Jawab kepada anak. ${ }^{2}$ Pendapat lain disampaikan oleh Khon, bahwa pola asuh adalah sikap orang tua berhubungan dengan anaknya. Sikap ini dapat dilihat dari berbagai segi, antara lain cara orang tua memberikan peraturan pada anak, cara memberikan hadiah dan

${ }^{10}$ Muhammad bin Ismail Al Bukhari, Al Adab al Mufrad: Kumpulan hadits-hadits Akblak, terj. Moh. Suri Saudari dan Yasir Maqosid, (Jakarta: Pustaka Al Kautsar, 2008), 12.

${ }^{11}$ Muhammad Fauzil Adhim, Salahnya Kodok (Yogyakarta: Mitra Pustaka, 1996), 12.

${ }^{12}$ Chabib Thoha, Kapita Selekta Pendidikan Islam (Yogyakarta: Pustaka Pelajar, 1996), 109. 
hukuman, cara orang tua menunjukan otoritas dan cara orang tua memberikan dan tanggapan terhadap keinginan anak ${ }^{13}$

Dengan demikian yang dimaksud dengan pola asuh adalah bagaimana cara mendidik orang tua terhadap anak, baik secara langsung maupun tidak langsung, menyangkut semua perilaku orang tua sehari-hari baik yang dapat ditangkap maupun dilihat oleh anak-anaknya, dengan harapan apa yang diberikan kepada anak (pengasuhan) akan berdampak positif bagi kehidupannya di masa depan. ${ }^{14}$

\section{Faktor yang Mempengaruhi Pola Asuh Orangtua}

Diana Baumrind, sebagaimana dikutip oleh Paul Henry Mussen mengemukakan beberapa aspek perilaku orang tua terhadap anak, antara lain:

1. Aspek kontrol, merupakan suatu usaha untuk mempengaruhi kegiatan berdasarkan sasaran atau tujuan, memodifikasi ungkapan perilaku bergantung, agresif, dan suka bermain serta memacu internalisasi standar orang tua.

2. Aspek tuntutan kedewasaan, menekankan pada penampilan kedewasaan secara intelektual, sosial dan emosional.

3. Aspek komunikasi orang tua dengan anak, menggunakan penalaran agar patuh, menanyakan pendapat dan perasaan anak.

4. Aspek asuhan orang tua, meliputi kehangatan (cinta kasih, perawatan dan keharuan), dan keterlibatan (pujian dan kegembiraan atas keberhasilan). ${ }^{15}$

\section{Pengertian Karakter}

Dalam wacana psikologi, terdapat dua istilah yang digunakan untuk menjelaskan kepribadian: yaitu personality dan character. Dua istilah ini sama-sama membicarakan tingkah laku manusia, hanya saja personality tidak mengaitkan pembahasannya pada baik buruk (devaluasi), sementara aksentuasi karakter justru pada penilaian baik-buruk (evaluasi). ${ }^{16}$

Istilah karakter diambil dari bahasa Yunani yang berarti to mark (menandai). Istilah ini lebih fokus pada tindakan atau tingkah laku. Secara etimologis, kata karakter berasal dari bahasa latin kharakter, kharassein, dan kharax yang maknanya "tools for marking", "to engrave", dan "pointed stake". Kata ini dimulai banyak digunakan pada abad ke-14 dalam bahasa Perancis caractere, kemudian masuk dalam bahasa inggris menjadi character dan akhirnya menjadi bahasa Indonesia karakter. ${ }^{17}$

${ }^{13}$ Chabib Thoha, Kapita Selekta Pendidikan Islam, 110.

${ }^{14}$ Chabib Thoha, Kapita Selekta Pendidikan Islam, 110.

${ }^{15}$ Paul Henry Mussen, et. al., Perkembangan dan Kepribadian Anak, terj. F.X. Budiyanto (Jakarta: Arcan, 1994), 399.

${ }^{16}$ Abdul Mujib, "Konsep Pendidikan Karakter Berbasis Psikologi Islam" Prosiding Seminar Nasional Psikologi Islami . 2012,5 .

17Zaim Elmubarok, Membumikan Pendidikan Nilai (Bandung: CV. Alfabeta, 2008), 102. 
Sedangkan menurut Kemendiknas, karakter adalah watak, tabiat, akhlak atau kepribadian seseorang, yang terbentuk dari hasil internalisasi berbagai kebijakan yang diyakini dan digunakan sebagai landasan sebagai cara pandang, berfikir, bersikap, dan bertindak. ${ }^{18}$

Pengertian karakter 1) menunjuk pada bagaimana seseorang bertingkah laku. Apabila berperilaku tidak jujur, kejam tentu orang tersebut memanifestasikan perilaku buruk. Sebaliknya, apabila seseorang berperilaku jujur, suka menolong, tentu orang tersebut memanifestasikan karakter mulia. 2) istilah karakter erat kaitannya dengan personality. Seseorang baru bisa disebut orang yang berkarakter apabila tingkah lakunya sesuai kaidah moral. $^{19}$

Maka dalam hal ini karakter merupakan istilah yang menunjuk kepada aplikasi nilai-nilai kebaikan dalam bentuk tingkah laku. Walaupun istilah karakter dapat menunjuk kepada karakter baik atau karakter buruk, namun dalam aplikasinya orang dikatakan berkarakter jika mengaplikasikan nilai-nilai kebaikan dalam perilakunya. $^{20}$

Sedangkan dalam literatur keislaman sendiri, terutama pada khazanah klasik, kata syakbshiyyah (personality) kurang begitu dikenal. Terdapat beberapa alasan mengapa hal itu terjadi: (1) Dalam al-Qur'an maupun Hadis tidak ditemukan term syakhshiyyah, kecuali dalam beberapa hadis disebutkan term syakhsy yang berarti person, bukan personality; (2) dalam khazanah Islam klasik, para filosof maupun sufi lebih akrab menggunakan istilah akblaq. Penggunaan istilah ini karena ditopang oleh ayat al-Qur'an dan Hadis Rasul; (3) hakekat syakhshiyyah tidak dapat mengkaver nilai-nilai fundamental Islam dalam mengungkap perilaku manusia, karena Islam bermuatan nilai, sementara syakhshiyyah tidak melibatkan penilaian baik buruknya. Islam justru menggunakan kata akhlak (bentuk jamak dari kata khuluq) yang identik dengan karakter.

Dalam psikologi Islam, istilah akhlak sesungguhnya identik dengan syakhshiyyah Islamiyyah, yang samasama memiliki arti karakter, karena istilah apapun yang disandingkan dengan Islam maka akan terikat oleh nilai baik-buruk.

Karakter diyakini sebagai sifat fitri manusia, sementara pada sisi lain karakter juga diyakini harus "dibentuk" melalui model pendidikan tertentu. Aristoteles meyakini bahwa individu tidak lahir dengan kemampuan untuk mengerti dan menerapkan standar-satandar moral, dibutuhkan pelatihan yang berkesinambungan agar individu dapat menampakkan kebaikan moral. Sementara Socrates meyakini bahwa ada bayi moral dalam diri manusia yang meminta untuk dilahirkan, tugas pendidikan adalah membantu melahirkannya. ${ }^{21}$

Manifestasi kerasulan Muhammad SAW. tersebut mengindikasikan bahwa pembentukan karakter dalam pandangan Islam merupakan kebutuhan utama bagi tumbuhnya cara beragama yang dapat menciptakan peradaban. Pada sisi lain juga menunjukkan masing-masing manusia telah memiliki karakter tertentu, namun

\footnotetext{
${ }^{18}$ Pedoman sekolah, Pengembangan Pendidikan Budaya dan Karakter Bangsa, (Jakarta: Kementerian Pendidikan Nasional Badan Penelitian dan Pengembangan Pusat Kurikulum. 2011), 8.

${ }^{19}$ Ratna Megawangi, Membangun SDM Indonesia Melalui Pendidikan Holistik Berbasis Karakter, dalam wmw.usm.maine.edu.com, diakses 4 Januari 2016.

${ }^{20}$ Euis Sunarti, Menggali Kekuatan Cerita (Jakarta: PT Elex Media komputindo, 2005), 1. 2008), 120.

${ }^{21}$ Bambang Q-Anees dan Adang Hambali, Pendidikan Karakter Berbasis Al Quran (Bandung: Simbiosa Rekatama Media,
} 
perlu disempurnakan. Tugas pendidikan adalah menyempurnakan dan membentuk kefitrian itu sehingga lebih optimal.

Islam hadir sebagai jalan untuk menyempurnakan karakter. Al-Qur'an adalah pedoman yang menghadapi masyarakat Arab yang berkarakter belum sempurna. Sejarah mencatat, bangsa Arab memiliki muru'ah (keutamaan dan kehormatan) tertentu yang terbatas pada kehormatan sukunya masing-masing. Melalui Al-Qur'an, secara perlahan dan bertahap, karakter dibentuk kedalam prinsip ketundukan, kepasrahan, dan kedamaian. Dalam Islam, kebagusan akhlaq menjadi indikasi derajat keimanan yang terbaik.

\section{Proses Pembentukkan Karakter}

Karakter, seperti juga kualitas diri yang lainnya, tidak berkembang dengan sendirinya. Perkembangan karakter pada setiap individu dipengaruhi oleh faktor bawaan (nature) dan faktor lingkungan (nurture). Menurut para developmental psychologist, setiap manusia memiliki potensi bawaan yang akan termanisfestasi setelah dia dilahirkan, termasuk potensi yang terkait dengan karakter atau nilai-nilai kebajikan.

Dalam teori psikologi, pembentukan karakter anak dimulai dari usia 0-8 tahun. Artinya dimasa usia tersebut karakter anak masih dapat berubah-ubah tergantung dari pengalaman hidupnya. Oleh karena itu, membentuk karakter harus dimulai sedini mungkin bahkan sejak anak itu dilahirkan, karena berbagai pengalaman yang dilalui oleh anak semenjak perkembangan pertamanya, mempunyai pengaruh yang besar dalam mewujudkan pembentukan karakter secara utuh. ${ }^{22}$

Pengembangan karakter seseorangan pada usia emas (golden age), terbukti sangat menentukan kemampuan anak dalam mengembangkan potensinya. Hasil penelitian menunjukkan bahwa sekitar 50\% variabilitas kecerdasan orang dewasa sudah terjadi ketika berada pada usia 4 tahun. Peningkatan 30\% berikutnya terjadi pada usia 8 tahun, dan 20\% sisanya pada pertengahan atau akhir dasawarsa kedua. Oleh karenanya sudah sepatutnya pengembangan karakter dimulai dari dalam keluarga yang merupakan lingkungan pertama bagi pertumbuhan karakter anak.

Karakter yang kuat dibentuk oleh penanaman nilai-nilai yang menekankan tentang baik dan buruk. Nilai ini dibangun melalui penghayatan dan pengalaman, meningkatkan rasa ingin yang sangat kuat, serta bukan hanya menyibukkan diri dengan pengetahuan. ${ }^{23}$ Oleh karena itu, jika sejak kecil sudah dibiasakan mengenal karakter positif, maka anak akan tumbuh menjadi pribadi yang tangguh, percaya diri dan empati, sehingga anak tersebut akan kehilangan jika tidak melakukan kebiasaan baiknya.

Dalam hal ini Erikson menyebutkan bahwa anak adalah gambaran awal manusia menjadi manusia, yaitu masa di mana kebajikan berkembang secara perlahan tapi pasti, dengan kata lain, bila dasar-dasar kebajikan gagal ditanamkan pada anak di usia dini, maka dia akan menjadi orang dewasa yang tidak memiliki nilai-nilai kebajikan ${ }^{24}$

${ }^{22}$ Arismantoro, Tinjauan Berbagai Aspek Character Building: Bagaimana Mendidik. Anak Berkarakter (Yogyakarta: Tiara Wacana, 2008), 124.

${ }^{23}$ Fauzil Adhim, Positive Parenting: Cara-Cara Islami Mengembangkan Karakter Positif Pada Anak Anda (Bandung: Mizan, 2006),

${ }^{24}$ Hurlock, E.B., Child Development. Sixth Edition (McGraw Hill Kogakusha International Student, 1981). 
Dalam konsep Islam, karakter tidak sekali terbentuk lalu tertutup, tetapi terbuka bagi semua bentuk perbaikan, pengembangan danpenyempurnaan, sebab sumber karakter perolehan ada dan bersifat tetap. Namun, sumber karakter itu hanya bisa bekerja efektif jika kesiapan dasar seseorang berpadu dengan kemauan kuat untuk berubah dan berkembang, serta latihan yang sistematis.

Ada tiga langkah untuk merubah atau memperbaiki karakter, dari karakter jelek menjadi karakter baik: ${ }^{25}$ Pertama, melakukan perbaikan dan pengembangan cara berpikir (terapi kognitif) dengan cara menumbuhkan pikiran-pikiran yang baik. Kedua, melakukan perbaikan dan pengembangan cara merasa (terapi mental), sebab cara merasakan sesuatu akan menguatkan dan melemahkan dorongan jiwa untuk melakukannya. Warna perasaan adalah cermin bagi tindakan terapi mental ini yang akan memunculkan kecintaan yang kuat terhadap sesuatu yang ingin dicapai. Ketiga, melakukan perbaikan dan pengembangan cara berperilaku (terapi fisik). Di sini dapat disimpulkan bahwa membentuk karakter yang baik diperlukan perpaduan atau kerjasama antara pikiran, hati dan tindakan.

\section{Aspek-aspek Pembentuk Karakter}

Untuk membentuk karakter anak diperlukan syarat-syarat mendasar bagi terbentuknya kepribadian yang baik. Menurut Megawangi ada tiga kebutuhan dasar anak yang harus dipenuhi, yaitu maternal bonding, rasa aman, dan stimulasi fisik dan mental. Maternal bonding (kelekatan psikologis dengan ibunya) merupakan dasar penting dalam pembentukan karakter anak karena aspek ini berperan dalam pembentukan dasar kepercayaan kepada orang lain (trust) pada anak. Kelekatan ini membuat anak merasa diperhatikan dan menumbuhkan rasa aman sehingga menumbuhkan rasa percaya. ${ }^{26}$ Menurut Erikson dasar kepercayaan yang ditumbuhkan melalui hubungan ibu-anak pada tahun-tahun pertama kehidupan anak akan memberi bekal bagi kesuksesan anak dalam kehidupan sosialnya ketika ia dewasa. Dengan kata lain, ikatan emosional yang erat antara ibu-anak di usia awal dapat membentuk kepribadian yang baik pada anak. ${ }^{27}$

Sudah diketahui orang banyak, ada tiga ranah besar yang menjadi garapan dalam ilmu psikologi, yaitu : kognisi, afeksi dan psikomotor. Terkait dengan bahasan karakter, ketiga ranah tersebut dijabarkan menjadi :

a. Knowledge dengan mengembangkan proses berfikirnya (Thinking),

b. Attitude dengan mengembangkan bagaimana mengelola perasaan (Feeling), dan

c. Skill dengan mengembangkan bagaimana individu bertindah (Doing).

Aspek-aspek karakter tersebut tidak akan berkembang dengan sendirinya secara liar, tetapi anak membutuhkan bimbingan, panduan dan keteladanan dari orangtua dan orang-orang dewasa lain di sekitar kehidupannya. Aspek-aspek karakter akan berkembang melalui proses: melihat, meniru dan kemudian akan disimpan atau dibuang oleh individu tergantung pada kebutuhannya saat itu. UNESCO menerjemahkan pembentukan karakter melalui aspek-aspek : learning to know, learning to do, learning to be dan learning to live together. $^{28}$

\section{Konsep Prophetic Parenting}

${ }^{25}$ M. Anis Matta, Membentuk Karakter Cara Islam, 82-84.

${ }^{26}$ Megawangi, R., Pendidikan Karakter untuk Membangun Masyarakat Madani, IPPK Indonesia Heritage Foundation. 2003.

${ }^{27}$ Papalia, D.F. and Olds, S.W. Human Development. 6th ed. (Boston : McGraw-Hill Companies, Inc. 2005)

${ }^{28}$ Karsidi, R., Pendidikan Berbasis Karakter, Makalah. Silaturahim di Ponpes Al-Muayyad Windan. Solo, 30 September, 2010. 
Pengasuhan (parenting) memerlukan sejumlah kemampuan interpersonal dan mempunyai tuntutan emosional yang besar, namun kurang dipengaruhi pendidikan formal. Biasanya para orangtua mengenal dan mempelajari pengasuhan/pola asuh dari orangtua mereka masing-masing, sehingga memungkinkan terjadinya perbedaan metode pengasuhan yang akan diterapkan ayah/ibu kepada anak-anak mereka di dalam rumah tangga. ${ }^{29}$

Pendidikan anak ala Rasulullah Saw pada saat ini lebih sering dikenal dengan istilah prophetic parenting. Konsep dalam prophetic parenting adalah mendidik anak dengan berkiblat pada cara-cara yang dilakukan Rasulullah shallallahu 'alaihi wasallam dalam mendidik keluarga dan sahabat beliau. Konsep Prophetic mendasar pada keteladanan (uswah hasanah) yang terdapat pada diri Nabi Muhammad Saw. Menjadi sebuah penekanan penting bahwasannya dalam prophetic parenting berlaku sebuah proses pendidikan bukan sekedar proses pengajaran, kerena dalam proses pendidikan selain mengajarkan ilmu juga menanamkan nilai-nilai.

Prophetic parenting dimulai dari membimbing setiap orang tua yang mendidik anak mulai dari mereka belum disebut orang tua. Maksudnya adalah prophetic parenting membimbing setiap pemuda dan pemudi untuk mempersiapkan diri mereka sebaik mungkin sebelum mereka menikah dan mempunyai anak. Menyiapkan segala ilmu yang lurus sebelum menjadi orang tua sangatlah penting karena dengan ilmu yang lurus setiap orang tua akan sukses dalam memimpin atau mengarahkan keluarganya menuju kebaikan. Persiapan ilmu tersebut berlaku baik untuk seorang pemuda yang akan menjadi suami maupun pemudi yang akan menjadi seorang istri. Orang tua (khususnya orang tua muslim) memiliki andil terbanyak dalam misi pendidikan karakter.

Dalam prophetic parenting, pendidikan anak juga terjadi sebelum terjadi konsepsi, calon bapak dan calon ibu disunahkan untuk memberikan perhatian (dalam bentuk do'a) agar bila konsepsi terjadi, janin yang akan berkembang dalam rahim ibu benar-benar dalam perlindungan dan keridhoan Allah SWT. Tahap ini berlangsung sejak proses pembuahan himgga anak lahir, yaitu sekira sembilan bulan. Meskipun relatif singkat, proses perkembangan pada tahap ini begitu penting, sebab pada saat hamil itulah seorang ibu mulai berperan dalam mendidik anak. ${ }^{30}$

Kemudian, saat kelahiran tiba, maka penerimaan atas kehadiran bayi dari kedua orangtua sangatlah penting. Momen menyambut kelahiran bayi merupakan hal yang penting dalam proses pendidikan anak. Kedua orangtua harus menunjukkan penyambutan atas karunia yang diberikan, maka orangtua harus menunjukkan kebahagiaan tersebut dengan wajah ceria dan penuh senyuman. Erikson menyatakan bahwa "trust" akan dicapai bayi, apabila sejak lahir dia mendapatkan penerimaan (acceptance) dari significant person. Beberapa hal yang perlu dilakukan orangtua saat menyambut kelahiran bayi antara lain: memberikan kabar gembira kepada keluarga besar, mengumandangkan adzan di telinga kanan dan iqamat di telinga kiri, melakukan tahnik atau mengunyah kurma, melakukan aqiqah, mencukur rambut dan memberi nama baik. ${ }^{31}$ 
Pendidikan anak harus dimulai dari sejak usia dini. Dari usia 1-7 tahun. Pada masa ini, Rasulullah SAW menyuruh orangtua untuk memanjakan, mengasihi dan menyayangi anak dengan kasih sayang yang tidak berbatas. Biarkan anak-anak bermandikan kasih sayang pada tahap ini. Pada usia 7-14 tahun orangtua mulai menanamkan disiplin kepada anak-anak dengan mengajar dan menyuruh mereka untuk mengerjakan solat. Bahkan apabila umurnya sudah sepuluh tahun, seorang ayah boleh memukul anaknya jika enggan mengerjakan solat. Kemudian pada usia 14-21 tahun. Orang tua sudah menukar penanaman disiplin dengan cara yang agak keras kepada yang rasional. Orang tua sudah semestinya mendidik anak dengan cara menjadikannya sahabat dalam berdiskusi, mengajaknya ikut dalam membincangkan masalah keluarga dan diberikan satu-satu tanggungjawab dalam hal-hal tertentu di rumah. Hal ini penting agar anak berasa dirinya punyai tanggungjawab mengambil berat hal-hal dalam keluarga.

Selanjutnya, pada usia lebih dari 21 tahun. Orang tua sudah boleh melepaskan anaknya untuk belajar menempuh hidup akan tetapi tetap melihat perkembangannya dan memberikan nasihat serta peringatanperingatan apabila anak tersalah atau terlupa. Ada orang tua yang terlalu memanjakan anak sehingga umur 14 tahun dan baru mulai mengajar dan menyuruhnya shalat pada usia mereka 15 tahun sehingga mereka bukan saja enggan melakukannya malah marah kepada ibu bapaknya. Jika kewajiban yg tertinggi (yaitu solat) yang telah diperintahkan Allah Yang Maha Agung diabaikan apa lagi dengan perintah dan suruhan orang lain termasuk ibu bapaknya.

\section{Metode Pendidikan dalam Prophetic Parenting}

1. Metode Keteladanan

Suri teladan yang baik memiliki dampak yang besar pada kepribadian anak, sebab mayoritas yang ditiru anak berasal dari kedua orangtuanya, bahkan dapat dipastikan pengaruh dominan berasal dari kedua orangtuanya. Rasulullah Saw. Memerintahkan kedua orangtua untuk menjadi suri teladan yang baik dalam bersikap dan berperilaku jujur dalam berhubungan dengan anak.

Kita sering memandang anak sebagai makhluk kecil, namun karena setiap waktu anak melihat perilaku dan perbuatan orang tuanya, maka kemampuan untuk meniru secara sadar atau tidak sangat besar. Pada mula dan awalnya anak akan selalu belajar dari lingkungan terdekatnya, yaitu orang tua. Mereka menyerap informasi dengan baiknya dari kelima indera mereka, bukan hanya perkataan orang tua tetapi sikap serta perilaku orang tua akan mereka serap juga, baik disadari ataupun tidak.

Kecenderungan manusia untuk meniru belajar lewat peniruan, menyebabkan keteladanan menjadi sangat penting artinya dalam proses. Apalagi bagi anak yang mudah meniru perilaku orang yang mempunyai ikatan emosi dengannya. Metode keteladanan ini senada dengan apa yang diungkapkan Albert Bandura dengan teori pemodelannya. Bandura percaya bahwa proses kognitif juga mempengaruhi Observastional Learning atau jika kita hanya belajar dengan cara trial-and-error, maka belajar menjadi sesuatu yang sangat sulit dan memakan waktu lama. Salah satu kontribusi yang sangat penting dari Albert bandura adalah menekankan 
bahwa manusia belajar tidak hanya dengan classical dan operant conditioning, tetapi juga dengan mengamati perilaku orang lain. Yang mana teori tersebut disebutnya dengan peniruan atau modeling. ${ }^{32}$

\section{Metode dengan Pembiasaan}

Pembiasaan secara etimologi asal katanya adalah "biasa”. Dalam Kamus Besar Bahasa Indonesia, "biasa" adalah 1). Lazim atau umum; 2). Seperti sedia kala; 3). Sudah merupakan hal yang tidak terpisahkan dari kehidupan sehari-hari." Dengan adanya perfiks "pe” dan sufiks "an" menunjukkan arti proses. Sehingga pembiasaan dapat diartikan dengan proses membuat sesuatu/ seseorang menjadi terbiasa. ${ }^{33}$. Inti dari metode pembiasaan adalah pengulangan.

Pembiasaan merupakan hal yang sangat ditekankan Rasulullah, sebab anak mendapat pengetahuan dari apa yang dilihat, dipikir dan dikerjakannya. Jika dalam kesehariannya anak sudah terbiasa melakukan halhal yang baik, maka akan terpatri sampai dewasa kelak. ${ }^{34}$

Rasulullah Saw. bersabda, "Dari 'Abd Allâh bin Mas'ûd ia berkata kepada bapaknya tentang bagaimana memperlakukan anak-anak mereka. Biasakanlah mereka dengan perbuatan baik, karena sesunggubnya kebaikan itu akan membiasakannya" (al-Tarbiyah al-Nabâwiyah li al--Thifl).

Hadis di atas sebenarnya menjelaskan bahwa untuk menciptakan anak-anak yang baik, maka perlu pembiasaan sejak kecil dari orangtua dan keluarga lainnya. Karena itu, orangtua terlebih dahulu harus menjadikan perbuatan-perbuatan baik sebagai kebiasaan dan kepribadiannya sehari-hari, sehingga mudah dicontoh oleh anak-anak.

Sebagai permulaan dan sebagai pangkal pendidikan, pembiasaan merupakan alat satu-satunya. Sejak lahir anak-anak harus dilatih dengan kebiasaan-kebiasaan dan perbuatan-perbuatan yang baik. Pembiasaan ini juga dapat diartikan pengulangan atau dalam istilah metode pembelajaran modern dikenal dengan istilah driil. Salah seorang tokoh psikologi yang memberi pengaruh terhadap proses pembelajaran dengan menggunakan teori pembiasaan adalah, Edward lee Thoorndike yang terkenal dengan teori connectionism (koneksionisme) yaitu belajar terjadi akibat adanya asosiasi antara stimulus dengan respon, stimulus akan memberi kesan pada panca indra, sedangkan respon akan mendorong seseorang untuk bertindak. ${ }^{35}$

3. Metode dengan Nasehat

Metode pendidikan melalui nasehat merupakan salah satu cara yang dapat berpengaruh pada anak untuk membukakan jalannya kedalam jiwa secara langsung melalui pembiasaan.Nasihat adalah penjelasan tentang kebenaran dan kemaslahatan dengan tujuan menghindarkan orang yang dinasehati dari bahaya serta menunjukkannya ke jalan yang mendatangkan kebahagiaan dan manfaat. Pendidikan dengan nasehat ini harus memperhatikan dua sisi yaitu mengarahkan kepada kebenaran dengan mengingkari kemungkaran. Dikala anak telah memahami keduanya, di sinilah sesungguhnya peran nasihat sangat dibutuhkan. Karena sesungguhnya daya nalar anak masih membutuhkan bimbingan supaya tepat dalam menyimpulkan apa yang dilihatnya.

\footnotetext{
${ }^{32}$ http://12008ars.blogspot.com/2013/06/teori-albert-bandura-modeling.html. diakses pada Kamis 20 Maret 2016

${ }^{33}$ Armai Arief, Pengantar Ilmu dan Metodologi Pendidikan Islam (Jakarta: Ciputat Pers, 2002), 110.

${ }^{34}$ Heri Jauhari Muchtar, Fikih Pendidikan (Bandung: Remaja Rosdakarya, 2005), 225.

${ }^{35}$ Nana Syaodih Sukmadinata, Landasan Psikologi Proses Pendidikan (Bandung: Remaja Rosdakarya, 2005), 169.
} 
Dengan nasihat inilah orang tua mendorong anak untuk memperbaiki kesalahan dengan menjelaskan akan sebab akibatnya.

Rasulullah saw, selalu memperhatikan waktu dan tempat untuk menasihati anak-anak. Orang tua harus mampu memilih kapan saatnya yang tepat agar hati anak-anak dapat menerima dan terkesan dengan nasihatnya. orang tua untuk memberi nasehat-nasehat dengan cara yang baik dan penuh

4. Metode Perhatian

Secara psikologis anak-anak membutuhkan — dalam pergaulan dan persahabatan dengan mereka kasih sayang dan perhatian. Anak-anak, kalangan remaja hingga orang dewasa pun sama-sama membutuhkan cinta dan kasih sayang. Kasih sayang merupakan hal yang sangat penting dalam pendidikan anak- anak.

Senada dengan makna kontekstual dari hadits di atas, Carl Rogers, salah satu tokoh psikologi behavioristik berpendapat bahwa proses suasana (emotional approach) dalam mendidik individu bukan hasil dari belajar. Artinya bahwa orangtua harus lebih responsif terhadap kebutuhan kasih sayang dalam proses pengasuhan maupun mendidik anaknya. Perasaan gembira, senang adalah hal yang dinginkan dalam proses pengasuhan.

5. Metode Pujian, Sanjungan dan Hukuman.

Rasullulah Saw. Mengingatkan tentang hal yang membawa dampak besar dalam jiwa anak yaitu dengan memberikan pujian dan sanjungan. Pujian dan sanjungan dapat menggerakkan perasaannya, sehingga dia dapat memperbaiki perilaku dan perbuatannya. Hati anak yang merasa senang mendengar pujian dan akan terus melakukan perbuatan terpuji.

Sedangkan untuk pemberian hukuman sendiri, dalam pola asuh Rasullullah Saw. Adalah bentuk pengobatan, hal ini dilakukan agar anak sadar bahwa masalahnya adalah masalah serius; bukan main-main. Dengan merasakan pedihnya hukuman, anak diharapkan dapat menyadari besarnya nilai kasih sayang dan kelembutan dari orangtuanya sebelum dihukum. Anak juga dapat merasakan pentingnya ketaataan, sikap dan perilaku baik mereka.

Dalam psikologi sendiri konsep pujian dan hukuman ini di kenal dengan Reward dan Punishment yang juga merupakan metode pembentukkan perilaku. Teori penguatan atau reinforcement juga disebut juga operant conditioning dan tokoh utama teori ini adalah Skinner. Skinner menganggap bahwa reward atau reinforcement merupakan faktor terpenting dalam proses belajar dan berpendapat, bahwa tujuan psikologi adalah meramal dan mengontrol tingah laku. ${ }^{36}$

Hukuman yang diterapkan kepada anak harus memenuhi tiga persyaratanya sebelum melakukannya, yaitu: sebelum berumur 10 tahun anak- anak tidak boleh dipukul; pukulan tidak boleh lebih dari tiga kali; diberikan kesempatan kepada anak untuk tobat dari apa yang ia lakukan dan memperbaiki keselahaannya tanpa perlu menggunakan pukulan atau merusak nama baiknya (menjadikan ia malu). ${ }^{37}$

Yang perlu digaris bawahi, bahwa hukuman dalam prophetic parenting bukanlah pembalasan dendam kepada si anak. Tujuan sebenarnya adalah pendidikan dan merupakan salah satu metode pendidikan, orangtua 
di sini dituntut untuk selalu waspada berinteraksi dengan anak, memahami tabiat mereka, bertahap dalam menghukum dan memilih hukuman serta cara menghukum yang pantas.

6. Metode kisah

Kisah dalam prophetic parenting di jadikan Rasullullah sebagai alat (media dan sarana) untuk menjelaskan sutu pemikiran dan mengungkapkan suatu masalah. Kisah yang baik akan banyak diminati dan dapat menembus relung jiwa manusia dengan mudah. Segenap perasaan mengikuti alur kisah tersebut tanpa merasa jenuh, begitu juga nilai nilai yang terkandung di dalamnya dapat dicerna oleh akal, diserap ke dalam hati untuk direalisasikan dalam tingkah laku. ${ }^{38}$

Dalam psikologi perkembangan anak usia dini, ada beberapa alasan mengapa menceritakan kisah dianggap efektif dalam memberikan pendidikan kepada anak. Pertama, kisah atau cerita pada umumnya lebih berkesan dari pada nasehat, sehingga pada umumnya cerita terekam jauh lebih kuat dalam memori manusia. Kedua,melalui kisah atau cerita anak diajarkan mengambil hikmah. Penggunaan metode bercerita akan membuat anak lebih nyaman dari pada diceramahi dengan nasehat.Dalam menggunakan metode bercerita hendaknya menyesuaikan dengan level kognitif anak. Dimana pada usia dini, level kognitif mereka masih pada operasional kongrit. Jadi cerita yang dibacakan atau disampaikan haruslah menyesuaikan tingkat kemampuan kognitif anak. ${ }^{39}$

\section{Penutup}

Anak adalah karunia Allah kepada manusia sekaligus merupakan amanah yang harus dijaga, diberi nafkah, didik dan dipertanggungjawabkan oleh orangtuanya. Cara strategis dalam membentuk karakter anakanaknya melalui pengasuhan yang tepat. Kesalahan dalam pengasuhan anak akan berakibat pada kegagalan dalam pembentukan karakter yang baik. Banyak keluarga yang gagal dalam proses pembentukan karakter, padahal kesuksesan seseorang tergantung kualitas karakter yang dimilikinya. Model parenting atau pengasuhan dalam keluarga merupakan dasar yang sangat penting bagi perkembangan karakter atau akhlak anak. Rasulullah Saw di utus sebagai suri teladan atau figur terbaik yang harus diikuti seluruh umat manusia termasuk cara mendidik dan mengasuh anak atau di sebut dengan prophetic parenting. Metode pendidikan yang telah diajarkan oleh Rasulullah Saw sudah seharusnya menjadi teladan dalam setiap langkah tidak terkecuali dalam pengasuhan anak. Di antara metode-metode pendidikan karakter atau akhlak bagi anak yang dapat diterapkan adalah pembiasaan, keteladanan, pemberian nasihat, pemberian sanjungan dan hukuman, memberikan perhatian dan pendidikan melalui metode kisah.

\section{DAFTAR PUSTAKA}

Abrasyi-Al, M. Athiyah. Dasar-dasar Pokok Pendidikan Islam. Jakarta: Bulan Bintang, 1970.

Adhim, Muhammad Faudzil. Salahnya Kodok. Yogyakarta: Mitra Pustaka, 1996. 
Adhim, Faudzil. Positive Parenting: Cara-Cara Islami Mengembangkan Karakter Positif Pada Anak Anda. Bandung: Mizan, 2006.

Al Barik, Haya Binti Mubarok. Ensiklopedi Wanita Muslimah. Jakarta: Darul Falah, 2006.

Al- Maliki, M. Alawi. Prinsip-prinsip pendidikan Rasulullah. Jakarta: Gema Insani, 2002.

Arief, Armai. Pengantar Ilmu Dan Metodologi Pendidikan Islam. Jakarta: Ciputat Pers, 2002.

Arismantoro. Tinjauan Berbagai Aspek Character Building: Bagaimana Mendidik Anak Berkarakter. Yogyakarta: Tiara Wacana, 2008.

Baharits, Adnan Hasan Shalih. Mendidik Anak laki-laki. Jakarta: Gema Insani, 2007.

Bukhari, Imam. Sahahidul Bukkari. Terj. Zainuddin Hamidi. Jakarta, Jilid I Cet ke 13.1992.

El-mubarok, Zaim. Membumikan Pendidikan Nilai. Bandung: CV. Alfabeta, 2008.

Hanan H. Anak Shalih, Investasi Dunia-Akherat. Hidayatulloh Edisi 03/XVIII/Juli 2005.

Hurlock, E.B. Child Development. Sixth Edition. McGraw Hill Kogakusha International Student. 1981.

Koesoema A., Dony. Pendidikan Karakter: Strategi Mendidik. Anak di Zaman Global. Jakarta: PT. Grasindo, 2007.

Megawangi, R. Pendidikan Karakter untuk. Membangun Masyarakat Madani. IPPK Indonesia Heritage Foundation. 2003.

Muhammad bin Ismail Al Bukhari, Al Adab al Mufrad: Kumpulan hadits-hadits Akblak, Terj. Moh. Suri Saudari dan Yasir Maqosid. Jakarta: Pustaka Al Kautsar, 2008.

Mussen, Paul Henry, et. al.. Perkembangan dan Kepribadian Anak. Terj. F.X. Budiyanto. Jakarta: Arcan, 1994.

M. Alawi Al-Maliki. Prinsip-prinsip Pendidikan Rasulullah. Jakarta: Gema Insani, 2002.

Muchtar, Heri Jauhari. Fikih Pendidikan. Bandung: Remaja Rosdakarya, 2005.

Mujib, “Konsep Pendidikan Karakter Berbasis Psikologi Islam ” Prosiding Seminar Nasional Psikologi Islami. 2012.

Nana Syaodih Sukmadinata, Landasan Psikologi Proses Pendidikan, cet-3. Bandung. Remaja Rosdakarya, 2005.

Papalia, D.F. and Olds, S.W. Human Development. 6th ed. Boston: McGraw-Hill Companies, Inc. 2005.

Q-Anees Bambang, Adang Hambali. Pendidikan Karakter Berbasis Al Quran. Bandung: Simbiosa Rekatama Media, 2008.

Sunarti, Euis. Menggali Kekuatan Cerita. Jakarta: PT Elex Media komputindo, 2005.

Santrock, J.W. Life-span Development. Terj. Achmad Chusaeri dan Juda Damanik. Jakarta: Penerbit Erlangga. 2002.

Suwaid, M. Nur Abdul Hafizh. Prophetic Parenting. Yogyakarta: Pro-U Media, 2010. 
Santrock, J.W. Psikologi Pendidikan. Jakarta: Kencana Prenada Media Group.2007.

Sarwono, Sarlito Wirawan. Pengantar Psikologi Umum. Jakarta: Bulan Bintang, Cet-Ke 2, 1982.

Shochib, Moh. Pola Asub Orang Tua dalam Membina Anak Mengembangkan Disiplin Diri. Jakarta: Rineka Cipta, 1998.

Soemanto, Wasty. Psikologi Pendidikan. Jakarta : PT Rineka Cipta, 1998.

Thoha, Chabib. Kapita Selekta Pendidikan Islam. Yogyakarta: Pustaka Pelajar, 1996. 
